\title{
Robert Gordon and the Rubies of Mogok: Industrial Capitalism, Imperialism and Technology in Conjunction
}

\author{
John Walsh, D.Phil. \\ Assistant Professor \\ Shinawatra International University \\ BBD Building (Viphawadi), 197 Viphawadi-Rangsit Road \\ Samsen Nai, Phayathai, Bangkok 10400, Thailand \\ Tel: 66-2-650-6031 E-mail: jcwalsh@siu.ac.th
}

\begin{abstract}
Robert Gordon's trip to the Mogok ruby mines in northern Burma, as reported in his testament to the Royal Geographical Society in 1888, represents one of the most blatant uses of travel as empire building in the Mekong Region. While European explorers and adventurers had been travelling to and along the region for centuries, most had been intent on mapping, surveying and categorizing its contents for purposes of their own profit, in one way or another. Gordon, while of course not unmindful of his own career, represents the traveller aiming to be of service to the greater power. He was strongly motivated by the desire to bring the ruby mines of Mogok into the reach of the British Empire through the building of a railway and the necessary infrastructure to pacify the countryside and its people, thereby enabling the enclosure of another type of commons.
\end{abstract}

Keywords: Capitalism, Imperialism, British Empire, Burma, Ruby mining

\section{Introduction}

The geography of the Mekong region is dominated by the difficult terrain of thickly forested mountains, crossing which is exacerbated by the monsoon climate. In the pre-modern age, the ever present danger of malaria would have been added to by wild animals such as rhinoceroses, tigers and snakes, in addition to leeches and numerous diseases that have subsequently been brought under some form of control, not least because of the way in which so much land has been brought under agriculture and into irrigation. Until the beginning of the nineteenth century, for example, much of central Thailand, which is now recognised as the fertile rice bowl of the region, was nearly all swamp which could be crossed by boat and was particularly unhealthy because of water-borne diseases (Higham and Thosarat, 1998: 13-4). By far the most convenient form of travel was along the river valleys or along one of the great rivers that rise from the Himalayas and flow from north to south in the Mekong region. Migration, trade and warfare were all constrained by this ease of movement along the north-south axis and was much less common along the east-west axis. Indeed, this tendency has continued to the present day a the north-south part of the Asian Highway Network is being completed in both road and eventually rail aspects, while the east-west part lags far behind in terms of funding, interest and the ability to overcome practical problems.

The western approach to uncovered terrain, terrain that has not been brought into 'civilisation,' that is, is to use technology to link it with the home country and to include it as one of a series of nodes that join together in international markets. As V.P. Scott O'Connor wrote about the extension of market power to Mogok, the ruby mining centre in northern Burma: "Little as the company may seem to shareholders in England, and to many who live in their sheltered parishes, in the shadow of old-world steeples, never having heard, it may be, of this little fraction of their mighty empire, the company in situ, in the valley of Mogok, is something of a power. It stands in a measure for the supremacy of the white man; for the colossus of capital; for the State. The company's agent is a potentate in his own right. Elsewhere, in nearly every other district of the province, there is only one great man, only one big house, only one repository of power. But at Mogok there are two; the head of the district and the company's agent. And there are some who would like to see an extension of the company's authority." (O'Connor, 2008: 45). This speaks to the heart of the imperial project: 'uncontrolled' terrain is brought into the sphere of the imperial power, embedded in the emergent capitalist networks and then control spreads over the remaining facets of society and governance, often under the pretext of the desire of the people involved or, at 
least, those petty capitalists in the indigenous population who have seen their prospects improve under the new arrangements.

This paper investigates the way in which the imperial agent, Robert Gordon in this case, investigated and surveyed the terrain and resources as yet unlinked to international markets and the implications of these acts. The Mogok ruby mines, in common with other mines in the Mekong region, appeared to external observers to be eminently suitable for exploitation by the tools of industrial capitalism and put to the service of empire. Yet practical difficulties, with which the local people had made some type of accommodation, militated against the designs of the imperial agents. This was once such example of the failure of imperialism in its capitalist aspect but success in its political aspect, since the British did not obtain the profits expected but all benefits apart from dependency and wage labour were denied to the local Burmese people.

\subsection{Methodology and Significance}

This paper is based on analysis of source materials produced by British and other European travellers in the Mekong Region (broadly defined as mainland Southeast Asia) and relation of the results to a theoretical framework. This framework is based on ideas propagated by theorists of empire-building and of the extension of capitalist enterprises around the world. Ideas integrated into the framework include those of, for example, Polanyi (2001, originally 1944), Anderson (2006) and Therborn (1978), among others. Such a framework (full exposition of which is beyond the scope of this paper) must be continually tested and refined through incorporation of analysis of additional sources both within the Mekong region and without it. It is particularly important to identify the impacts of empire upon the Mekong region because of the difficulties, to use a neutral word, that so many governments that have been apparent in the region subsequently have faced in establishing stable, efficient and equitable states. To some degree and attempting to calculate the extent of that degree is part of the purpose of this paper, those difficulties have been caused by the legacies of imperialism, so many of which have yet to be properly documented, unpacked and inspected.

\section{The Act of Observation}

Modern physics confirms that the act of observation has a direct effect on the nature of events and also changes in some way the observer. In the pre-modern world, the observation made could only be recorded through the words or sketches of the individual observer or a correspondent and was, therefore, subject to a variety of biases and inaccuracies, as well as being very limited in scope. The advent of the mechanical means of reproducing observations, through the photograph and the printing press for example, significantly changed the importance of the observations initially made in places far from home. The observations became much more accurate and, apparently, scientific in nature and they could be spread much more extensively throughout desired target audiences. The excitedly told adventure story and the authenticity of the personal submission might have been sufficient to inflame the imagination of a monarch or another powerful sponsor but, for capitalism to bring forth its joint stock companies and its numerous middling investors, accurate replication of images and objectively produced facts were necessary. As Benedict Anderson has observed, following Hegel's observation that the newspaper has superseded morning prayers, “... each communicant is well aware that the ceremony [s] he performs is being replicated simultaneously by thousands (or millions) of others of whose existence he is confident, yet of whose identity he has not the slightest notion. Furthermore, this ceremony is incessantly repeated ay daily or half-daily intervals throughout the calendar (Anderson, 2006: 35)." In other words, this is the emergent form of print capitalism.

This indicates a dynamic process of observation that changes not only in terms of what is being observed but of how the observer intends observations to be used and how the observations may be mechanically reproduced. Such an approach to observing the Mekong region indicates that the process has not been static over the centuries. Earlier and indeed subsequent visitors to the region have had quite different intentions to the people they found there and this has often been quite closely related to the nature of power relations between them. For example, perhaps the first outside observer from whom a coherent account exists is the Chinese ambassador Zhou Daguan, who visited the Angkor court at the end of the thirteenth century. His observations of Khmer society and state highlight the differences from Chinese society that he noted with an apparent sense of innate superiority. He noted, for example, curiosities and security issues to the court as well as advice on how to promote Chinese interests through success in commerce: "The local people who know how to trade are all women. So when a Chinese goes to this country, the first thing he must do is take in a woman, partly with a view to profiting from her trading abilities (Zhou Daguan, 2007: 70). In the centuries that have followed and as 
Europeans began to join in the observation of the Mekong region, the observations tend to have followed similar patterns insofar as there were similar motivations for the travels to be made (as explained in the next section). Terwiel (1989: 250-7) summarises the observations as falling into the categories of the population, the role of government, ethnic groups and nature.

This leads to one final perhaps contradictory notion. The rubies of Mogok are celebrated not just as beautiful but as unique artifacts: the means of cutting and polishing them to locate the beauty within which waits to be discovered by the craftsperson is praised as a work of art. Yet the means of producing this artistic beauty is both a form of industrial production through its precision tools and the results are then disseminated through the organs of print capitalism. As Adorno observes, ""The discovery of genuineness as a last bulwark of individualistic ethics is a reflection of industrial mass-production. Only when countless standardized commodities project, for the sake of profit, the illusion of being unique, does the idea take shape, as their antithesis yet in keeping with the same criteria, that the non-reproducible is the truly genuine (Adorno, 2005: 155)."

\section{The Categories}

It is possible to divide the early observers of the Mekong region into different categories, although it should be borne in mind that some observers cross the categories or may be argued to transcend them altogether. The categories are: early adventurers; prospectors for souls; surveyors for empire; surveyors for local rulers and surveyors for private consumption. The early adventurers were those mainly Iberian individuals who believed they could loot, kill and swashbuckler their way to fame and fortune in the distant Chersonese. That they failed to do so tends to be because at least in part they possessed no advantage in technology, physique or organisation. Prospectors for souls were those clerical persons engaged on often lengthy embassies to prominent local rulers with a view both to opening evangelical missions among the poor (or at least the middle classes) and also to converting the rulers and the courts themselves. Considerable excitement surrounded the apparent approach towards Catholicism of the Siamese King Narai the Great, which was an approach that never quite converged with reality (e.g. Smithies, 1996). The surveyors for empire were those, Robert Gordon included, who sought to map and document the terrain and geography of the Mekong region with a view to capturing its resources for the purposes of the imperial power sponsoring them. For the imperial surveyors, then, people and their lives are unwanted interlopers in a landscape which should be more properly developed and brought into the international market system for greater efficiency and in line with modern conceptions of the world. As will be seen, this is precisely the approach taken by Gordon. Surveyors for local rulers are a similar group of people but with the difference that the profit was intended for local rather than imperial powers. Early observers had little truck with local rulers, unless it was convenient for them to do so, partly on the basis that they had not constructed their states and legitimacy along western lines with proper state apparatus such as formally demarcated borders, international treaties and generally modern institutions. As part of their surveying, civilizing tasks, imperial observers felt they should be involved in drawing local rulers into the wider world. Consequently, once this had been achieved, it became increasingly acceptable for foreigners to serve the local rulers and help provide them with the benefits of the modern imperial order. Finally, the surveyors for private consumption are those who, until the present day, are those who travel to the Mekong region with a view to acquiring some personal ownership of it, either through the processes of the memory or through a mechanical reproduction of images of the area, frequently with the sight of the observer superimposed on the landscape and at the centre of the photographs or videos involved. As previously observed, it is not always possible to classify individuals wholly as belonging in one category or another. During the Lagrée-Garnier expedition to find the source of the Mekong, for example, the official artist [Louis Delaporte] was responsible both for scientific studies of the landscapes, flora and fauna as well as contributing to cartography, while also occasionally including the representations of one or more members of the party within the landscapes depicted (Osborne, 1996: 52). On some occasions, the expedition members are passive in front of the landscape; on other occasions, they are actively interacting with the people of the region and of their social and economic activities.

\section{Gordon's Task}

Gordon was quite clear about the nature of his task and the implications of it. He makes this evident at the beginning of his report to the Royal Geographical Society:

"When Upper Burma was annexed to the Empire in 1886 negotiations were opened with commercial firms for the working of the ruby mines near Mogok, some 60 miles north of Mandalay. Among the competitors were 
Messrs. Streeter \& Co., who were requested by the Government to send representatives to the mines, and I was asked to survey and report on the mining district by the concessionaires (Gordon, 1884)."

There is, quite clearly, no equivocation about the right that the British Empire has not just to occupy and control this land but also to exploit its resources for the purposes of the imperial system. Once the land has been claimed by the empire, therefore, it is perhaps irrevocably linked with the sphere of international capitalism in its various manifestations. This becomes clear when the various aspects of linking Burma to Britain are examined. These include, above all, the ultimate goal of trade access to Southern China, which had long been regarded as the greatest possible commercial market and one which (in modern parlance would be described in terms of economies of scope and scale) must be pursued beyond any others.

Additionally, there was also the idea that the creation of infrastructure would inevitably lead to a general improvement in economic conditions in the vicinity of the new construction. This is an idea which has persisted until the present day and is found in the discourse of the Asian Development Bank and similar institutions. For example, as Madhur, Wignaraja and Darjes (2009) write: "Connecting countries through roads is a pivotal element of regional integration. Such connectivity across borders brings many benefits, including improved competitiveness of production networks, better trade flows, and reductions in development gaps between rich and poor countries." Yet it has not been established how such benefits will take place and, in the nature of Schumpeterian creative destruction, the types of economic activity may not be entirely desirable or at all predictable. Modern infrastructure development, for example, has promoted human trafficking as well as legal and illegal migration and the linking of previously remote market institutions has acted in some cases to eliminate the business opportunities of local people (Southiseng and Walsh, 2010). Gordon himself linked the economic possibilities with the governance issues central to imperialism: "At present, 162 miles of railways are opened to Tonghoo and pass through rich cultivation and wild lands rapidly being reclaimed and transformed. The local traffic is already heavy, and with the through traffic to the Shan states more than pays for working ... Projects are being considered for extending this irrigation scientifically under Government control, so that in a short time the entire railway may pass through a richly cultivated country with greatly increased local traffic, besides tapping the Shan trade routes, while it will have immense importance also in facilitating civil and military operations in Upper Burma (Gordon, 2008:88)." This passage indicates the scientific, objective and replicable nature of the railway's construction and, consequently, of its suitability for capitalist investment. It is inextricably linked with the Haussman-like reconfiguration of modern Burma symbolized most strongly by the relocation of the capital city away from Rangoon (Yangon) to Naypyidaw (Preecharushh, 2009:71-85). Where Gordon foresaw Mogok becoming linked as a node in the international market chain linking northern Burma and ultimately China with London and the ports of Britain, the Than Shwe government moved deliberately to break that chain, ideologically at least, by moving the capital to a place that was not part of the imperial linkage. As part of the imperial system, the capital of Rangoon was necessarily located on the coast, where it most conveniently linked with the seaborne trade routes that were then the most efficient means of transferring resources from the periphery to the core. The modern Burmese government did not move the capital to Mandalay, which was the last independent capital because at least in part that city has become so deeply embedded in international commercial networks that it has lost its symbolic Burmese importance. Instead, a new location at Naypyidaw which was not linked to such networks but had some cultural and historical resonance. Then, new networks are created which are considered to be under the control of authentic Burmese interests.

However, these changes to the landscape can only be justified when they are accompanied by improvements in efficiency. This is generally measured in scientifically verifiable facts and figures. Gordon describes the proposed changes as follows:

"The weekly mail from London reaches Rangoon in twenty-three to twenty-five days; and direct steamers do the ocean route of about 8000 miles in thirty to forty days. Formerly the only route to Mandalay was the river journey of some 600 miles, which took two to three weeks to accomplish, owing to delays at intermediate stations for cargo; but now 160 miles of rail to Prome on the Irawadi cut off one half the distance in a few hours, and express steamers run thrice weekly between Prome and Mandalay, in three days up and two down (Gordon, 1884)."

Here, practical issues meet with ideological issues. The distant lands of Upper Burma become encompassed in the empire in terms that are measurable and in which simultaneity of action is confirmed. As Anderson noted, the spread of print capitalism as noted above coincided with the notion that previously imaginary locations become 'historically clocked' (Anderson, op cit) or, in other words, brought simultaneously into the same 
conceptual space as well-known nearby locations in that they can be monitored on the same clock face. Steamers and trains and other forms of transport could be mapped across previously unknown spaces with a (perhaps occasionally spurious) precision that may then be used to calculate the profits and losses accruing to various transactions. In doing so, the transformation seems to confirm the observation of Rosa Luxemburg: "All conquerors pursued the aim of dominating and exploiting the country, but none was interested in robbing the people of their productive forces and in destroying their social organization (Luxemburg, 1968: 372)."

Bringing the country under control required a military presence on the ground and this was provided by a core of British troops accompanied by various allies and dependents. Opponents, termed 'Shans and Dacoits,' fell back on their prepared positions but were ultimately helpless when it came to withstanding what in this case was the telling technological superiority of the invaders, especially in the absence of any powerful ideology of resistance or nationalism. The situation after conquest was quite different, since the Burmese were very willing to mount resistance in the form of guerrilla actions against the occupiers (Stewart, 2003: 173-5).

Actions in northern Burma were matched by an intensifying degree of interest back in Britain. Hughes (1997) illustrates the interest in the swelling bubble of potential investment in London amid many comical scenes of prominent financiers being required to 'effect burglarious entries' into their own premises owing to the swelling crowd shoehorning themselves in to hear of the potential profits to be made. Unfortunately for these investors, the inability of industrial capitalism to extract the required profits from the difficult terrain of northern Burma meant that their own aspirations were to be frustrated and they became acquainted with the negative consequences of placing their capital in a failed venture.

\section{The Failure of Industrial Capitalism}

With the Mogok region mines brought under imperial control, little time was wasted before the joint stock investment was converted into the type of large-scale machinery envisaged as necessary to reap the desired profits. In doing so, the preceding petty capitalists had to be obliged to remove themselves: wherever the Europeans travelled in the Mekong region, they found Chinese already there and, in general, earning a living through some form of petty or primitive capitalism. This, in the case of the mines of Mogok, took the form of capturing the market for transactions involving discovered gems and supplying the technology that was used to extract stones at a low rate. It did not seem to occur to the British agents of empire that there were good reasons for using this level of technology. It was, instead, assumed that more and larger machinery would be better and inevitably produce greater profits. As Garnier proclaimed, somewhat breathlessly, when trying to drum up support for a further expedition to the region: "Laos is marvelous. But even more so is Yunnan with its great mineral resources; with the high blast furnaces, the hissing machines, the forges, the rolling mills that Europe could install there in abundance, what might it not become (Garnier, 1872, in Osborne, 1996:195)?" When the Europeans first began to penetrate the Mekong region, their ambitions were limited by the superior power and technology that they found there. By the end of the nineteenth century, though, their confidence in the superiority of their organisation, management and physical technology was complete. Alas for them, though, their preconceptions came unstuck.

“... it is one thing to know that there are rubies of great price stored in the interior of a mountain in front of you; it is quite another to find them. The company, in short, embarked on a policy of adventure. Its slender capital was poured out like water. Here and there a ruby of price was found; here and there a pocket of unfractured stones rewarded the arduous labour of those who drilled into the darkness of the hills. And meanwhile anxious shareholders waited for a dividend that never came; an anxious Government, prone to the prompt collection of its dues, waited for its rent; and hope, delusive, receded farther and farther away as the company's capital approached extinction (O'Connor, 2008: 50-3)."

The problems began to multiply as calculated predictions failed to come true and the vital capital was revealed to be inadequate. No matter what was tried and what reconfiguration of labour and machinery was offered to the mines, success remained elusive. Perhaps this was a case of luck and perhaps it was a case of a failure of capitalism? It is certainly true that many although not all mining operations in the Mekong region remained small scale in nature until the recent past. Milton Osborne, for example, writing of the infamous Pailin mines of Cambodia in the 1960s describes the low level of technology and the dangerous, labour-intensive work:

"As I walked about the town and its outskirts I found the 'mines'. They were not at all what I expected. Many were only shallow trenches and holes in the ground with coolies lifting baskets of earth from the bottom to helpers at the top who then grubbed through the earth looking for stones. Larger enterprises were still far 
removed from a stereotyped image of a mine, consisting merely of trenches and holes but located close to running water that was used to sluice the earth away ... the prospects for work elsewhere [were] so limited that [workers] had come to Pailin where the work was hard but there was always the chance that a rich find of stones could bring temporary relief from poverty and hard physical labour. He was clearly a person who resented his low position and who found the dominance of the Shans in Pailin - they owned the most productive mining sites and controlled access to the water necessary for washing away dirt from the gem stones - particularly galling (Osborne, 2004, p.41)."

This scene might be replicated any number of times throughout the region. Some large-scale ventures have succeeded in terms of profitability, such as the case with Australian investment in Laos, but there are more examples of failure.

\section{Conclusion}

As Joseph Schumpeter memorably observed, capitalism is an endless process of creative destruction. The old is continuously replaced by the new inevitably: it is by no means necessary for the new to be in any way better or superior to the old just different. That this is so in the imperial project in the Mekong region is borne out by the transformation of mining projects under European control. The old ways of managing the economic activity were replaced by new ones which appeared superficially to be advanced, scientific and efficient in nature. In reality, the new form of industrial capitalism turned out to be disastrous in the terms of profit maximization that formed its purpose from the imperialists' point of view but which served the processes of colonization all too well from the point of view of those being colonized. This was not a unique phenomenon. Margaret Slocomb's investigation (2007) of the development of rubber plantations in French Indochina reveals the way in which that industry combined misery for coolie labour, painfully thin margins for the rubber plantation investors in the face of global changes in the economic environment and the irreversible enclosure of the commons that once provided sustenance to the people of the country: “... the development of the Cambodian rubber plantations followed the classic pattern of transformation to a modern market economy. Land was alienated from the public domain, from nature, in fact, and transferred to private property. It was commodified, packaged in the form of a concession and sold to the owners of capital, who were absentee investors without any personal identification with the land itself. The revenue from the transfer of land was passed into the coffers of the colonial administration to be used for the purposes of national development and state-building (Slocomb, 2007: 66-7)."

There are clear similarities between the two industries. In these cases, the economics of empire represented a failure for private investors but it is not inevitable that this is the case. After all, the British-run rubber plantations in Malaya were highly successful commercially and there are numerous examples from the Mekong region itself of successful and profitable extraction of resources. However, it does show that there remain clear limits to what ideology and technology can achieve, no matter how much it might be wished otherwise.

\section{References}

Adorno, T. (2005). Minima moralia: Reflections on a damaged life. London and New York: Verso Books.

Anderson, B. (2006). Imagined communities, revised edition. London and New York: Verso Books.

Gordon, C.E., R. (2008). "On the Ruby Mines near Mogok, Burma," Proceedings of the Royal Geographic Society and Monthly Record of Geography, Read at the Evening Meeting, February $27^{\text {th }}, 1888$ in O'Connor, 2008, loc. cit., pp.87-101.

Higham, C. and Thosarat R. (1998). Prehistoric Thailand: from early settlement to Sukothai. London: River Books.

Hughes, R.W. (1997). Ruby and sapphire. Boulder, Co: RWH Publishing. [Online] Available: http://www.ruby-sapphire.com.

Luxemburg, R. (1968). The accumulation of capital. New York: Monthly Review Press. Translated by Agnes Schwarzchild.

Madhur, S., Wignaraja, G. and Darjes, P. (2009). Roads for Asian integration: Measuring ADB's contribution to the Asian highway network. ADB Working Paper Series on Regional Economic Integration, 37.

O'Connor, V.P.S. (2008). Rubies of Mogok: Thabeit-Kyin, Capelan, Mogok. Bangkok: White Lotus.

Osborne, M. (1996). River road to China: The search for the source of the Mekong, 1866-73. Singapore: Archipelago Press. 
Osborne, M. (2004). Before Kampuchea: Preludes to tragedy, second edition. Bangkok: Orchid Press.

Polyani, K. (2001). The great transformation: The political and economic origins of our times. Uckfield: Beacon Press.

Preecharushh, D. (2009). Naypyidaw: The new capital of Burma. Bangkok: White Lotus.

Slocomb, M. (2007). Colons and coolies: The development of Cambodia's rubber plantations. Bangkok: White Lotus.

Smithies, Michael, ed. (1996). The Siamese memoirs of Count Claude de Forbin, 1685-1688. Chiang Mai: Silkworm Books.

Southiseng, N. and Walsh, J. (2010). Contrasting male and female entrepreneurs' cross border trading experiences prior to and after the construction of the Second Lao-Thai Friendship Bridge. Paper presented at the International Workshop on Gender, Economic Integration, and Cross-border Road Infrastructure Development: Poverty and Mobility in the Context of Asia. AIT, Bangkok.

Stewart, A.T.Q. (2003). The pagoda war: Lord Dufferin and the fall of the kingdom of Ava, 1885-6, second edition. Bangkok: White Lotus.

Terwiel, B.J. (1989). Through travellers' eyes: An approach to early nineteenth century Thai history. Bangkok: Editions Duang Kamol.

Therborn, G. (1978). What does the ruling class do when it rules? London and New York: Verso Books.

Zhou Daguan. (2007). A record of Cambodia: The land and its people. Chiang Mai: Silkworm Books. Translated with an introduction and notes by Peter Harris. 